\title{
A DESIGNER IN THE INTERSECTION OF ISLAMIC-OTTOMAN ARCHITECTURE: THE ARCHITECTURAL CONCEPT OF TURGUT CANSEVER (1920-2009)
}

| Received November 16 th. $^{\text {th }} 2018$ | Accepted February $1^{\text {st. }} 2019$ | Available online December $20^{\text {th. }} 2019$ | DOI http://dx. doi.org/10.18860/iia.v5i4.5346 |

\section{Berna Üstün}

Department of Architecture Eskişehir Eskisehir Technical University, Turkey bustun2012@gmail.com

\section{F.Özge Güven Ulusoy}

Department of Architecture Eskişehir Eskisehir Technical University, Turkey foguvenulusoy@gmail.com

\section{Gamze Şensoy}

Department of Architecture Eskișehir Eskisehir Technical University, Turkey gamze.snsy@gmail.com

\section{Fatma Kolsal}

Department of Architecture Eskișehir Eskisehir Technical University. Turkey fatma.kolsal@gmail.com

\begin{abstract}
Architects in the history of architecture try to be understood by their ideas that their designs need to be present on earth. Turgut Cansever (1920 2009) is an important opponent architect who was prized by Aga Khan Awards for architecture three times in his professional life and established his architectural understanding of the architecture of Ottoman and Islamic culture. This study aims to describe the life and work of the architect and his opinion about Islamic-Ottoman Architecture. Setting his architectura conception on a broader belief, Cansever strengthens his apprehension of architecture with his practice and literature studies. This unique approach in his works is shaped by a point of view that criticizes modernity but aims to validate it by reinterpreting in line with Islamic architecture. The references in the background of the structures of Cansever is thought to be too complex to read at a time. The understanding of Cansever's original designer perspective will be possible through the discussion of his synthesis resulted from the thoughts of Islamic architecture, Ottoman Architecture and modern architecture, and their reflections on his structures.
\end{abstract}

KEYWORDS:

Islamic Culture, Ottoman Culture Ottoman Architecture, Modern Architecture, Turgut Cansever, Aga Khan Awards for Architecture

\section{INTRODUCTION}

Turgut Cansever is one of the unusual Turkish architects who thought, produced and discussed a lot about his ideas and architecture on different platforms. When we try to understand his architecture and thought system from his writings, we see a Cansever who defines his works in the field of architecture as "an effort to reflect consciousness into the world of shapes" [1]. Cansever, who did not seek "a new Islamic architecture" with the view that religion he believes has not a specific (and single) architectural expression or orientation, argued that, on the contrary, Islam allowed different perspectives under the same common denominator. According to Cansever who argues that "native" architecture cannot be created by imported discourse, Islam is not a rural culture, but a city culture. The Ottoman city, which existed in this environment, is a structure that is compatible with the reality of life, existence, and creation [2].

Cansever, who thinks that the "existence" is the result of the actions and formations that are added together, believes that architectural production should be an addition to the past and preparation for the future [3]. His architectural identity, which is observed in his structures since 1949, will be expressed, in this paper, with his holistic structure of the designer view developed in parallel with the way of life and thought.

\section{METHODS}

In this context, first of all, the ideas of Cansever on Islamic culture - architecture and Ottoman culture architecture will be studied. The chronological explanation of his important building designs will contribute to the analysis of his ideas in the background. Afterward, Cansever's buildings will be grouped under three main headings by taking into consideration the periodical distinction of Prof. Dr. Uğur Tanyeli, who has important findings of Turgut Cansever. In order to grasp the references in the background of his designs, eight structures will be evaluated regarding specific parameters. Finally, an evaluation of the synthesis expressed by the tables will be made.

\section{DISCUSSION \\ HIS LIFE AND WORKS}

Cansever, who was born in Antalya in 1920, met with Halil Dikmen, Mazhar Şevket İprişoğlu, and Sedad 
Hakkı Eldem at Istanbul Fine Arts Academy. By deciding to study architecture, he became assistant to Sedad Hakkı Eldem. In 1946 he graduated from Istanbul Fine Arts Academy, Department of Architecture [4]. He was influenced by Ernstdiez, Professor of Islamic Art and history, throughout his life. In 1949, he gained the title of art history doctor (Ph.D.) with his thesis titled "column headings in Ottoman and Seljuk Architecture" under the guidance of Prof Dr. ErnstDiez at Istanbul University Faculty of Letters [5]. He studied 14 Anatolian cities and 11 structures for his thesis. His thesis was published in 2010 under the title of "following the eternal space: Seljuk and Ottoman column headings."

In 1960, Cansever received the title of Associate professor with his thesis "Problems of Modern architecture," examining five important designers of contemporary architecture, including Frank Lloyd Wright, Le Corbusier, Walter Gropius, Alvar Aalto and Mies van der Rohe [6]. He served as a faculty member between 1950 and 1951, and until 1980, he served as a consultant in many public institutions and organizations. Cansever who approached the problems of modern architecture with an emphasis on environmental and cultural values in various areas of design and applications, won the Aga Khan Awards for Architecture three times with the "Turkish Historical Society building" in Ankara, "Ertegun house" in Bodrum and "Demir holiday houses." Understanding Istanbul (1998), Not Place the Dome on the Ground (1997), City and Architecture in Islam (1997), House and City (1994), and City and Architecture (1992) are his books [4].

\section{HIS OPINIONS ON ISLAMIC ARCHITECTURE, OTTOMAN} ARCHITECTURE, AND MODERN ARCHITECTURE

He wanted to think and live the way of life, culture, art, architecture, that is, all the components of social and personal life which have been shaped around the axis determined by the Islamic religion, in a solid unity. He holistically thought not only all the abstract and concrete things that human beings create but also holism including those that exist in nature. It can be said that this idea is directly related to the concept of "unity of existence" of Sufism, which considers the universe as a single holistic entity. By considering the fact that the changes in the name of Westernization that the Turkish society has been experiencing for two centuries inevitably destroyed the spiritual inner consistency and integrity of human beings, Cansever dreamed of reestablishing this unity within a scope covering the architecture as well [2].

The modernist design language, which Cansever considers as a possibility in the early years, transformed into a unique thinking structure with the inclusion of locality, diversity, and existential analyses on individuals [7].

Cansever, who thinks that the cities reflecting the Islamic feature in the highest perspective are Ottoman cities, pointed out the style integrity of the whole city and the neighborhood, created with the light of high willpower and high level of knowledge and talent, by using architectural element standards. He stated that the tectonics constituting the Ottoman city had a great unity that was established by taking into consideration the environmental conditions [8]. Cansever stated that both the naturality and beauty of the Ottoman cities were due to the variety of one, two, threestory houses. It is more luxurious than a monotype layout of an apartment [9]. According to Cansever, the difference separating the Islamic Art and architecture from the west was made possible by choice of mechanical integrity rather than organic integrity. As an example of tectonic and cubistic integrity, he points out the relationship between house and neighborhood in Ottoman architecture, and the strength of integrity of the houses in the same quality and same value, both in the building scale and in their relations with each other. He states that the construction of architectural solutions using pre-defined standard elements is a product of progressive thought. He believes that the superiority of the Ottoman house is due to the product of a system that can be called a prefabricated system with these standards and that the common standards for the continuity of our architectural culture should be investigated and protected. Cansever tries to relate the principles of modernism and architecture of the geography in which the Ottoman Empire ruled for some time. He also argues that it reached the Universal solutions, values, and standards sought by modernism, by being influenced by Anatolia, North Africa, Islam and Ottoman architecture, not by Western Europe's Christian or Baroque culture [3], [10]. Turgut Cansever reconciled his architectural discourse with a systematic plan of order, which he described as "standards" and regarded as a part of a cultural continuum. In Cansever's opinion, the standards are the primary subunits of the entity and cultural codes that form a whole. The structure defines a systematic standards scheme from the top-level form to the smallest elements. When the standards of the construction system, the standards of the internal and external relations, and the standards of the window and the door reached to the whole, the structure itself emerges. Cansever first discussed his ideas about standards in the Diyarbakır college competition project. He created a system with the repetition of the size that he developed through modular standardization. He used this system by renewing and diversifying in different periods. Turgut Cansever emphasized the need for standards to provide flexibility to respond to the needs of different social structures [7].

The results of the East-West journeys done between 1946-1950 by Turgut Cansever created different influences in the Turkey architecture environment. His thoughts, writings and speech on the theory of architecture after returning from the West can be considered as an attempt to convey contemporary art/architecture discussions to the Turkish architectural environment. He prepared a debate platform on the re-interpretation of Western architecture. Cansever, who visited Le Corbusier's offices and structures in Paris, was influenced by his 
declaimer, revolutionary, and productive features. In the Anatolian Club, Turkish Historical Society and Karatepe Archaeological Border and Excavation House, he converts the Corbusier architecture into production by reading and re-internalizing it. In his thesis titled "Issues of modern architecture," he talked about issues such as "human scale, social reality, the use of the building and the creation of the environment," with the experiences which he collected from Europe. He saw the works of Frank L. Wright, Le Corbusier, Walter Gropius, Alvar Aalto, and Mies van Der Rohe, so simple architectural interpretations, use of materials, niceties in Scandinavian countries enriched his world of thought. To interpret the world is to collect the variations of the precious materials of universal Islamic architecture and to reach new rich interpretations [1].

He described all Western art as an ideological conditioning instrument restricting human freedom of action and thought, starting with the earliest examples and extending to modernism, and suggested that art has a liberating function in the Islamic world. Cansever, however, did not attempt to idealize the past from an architectural point of view, nor did he suggest that the religion he believes had a specific (and single) architectural expression or orientation. He thinks that Islam allows different perspectives under the same common denominator. He said that a style was a prospect belonging to a "shape" and that the shape concept existed within the "space-time" dimension. This discourse allows us to understand that he is not an eclecticist or historicist. Cansever, who does not think that the reality is constant and unchanging, believes in the concept of superior reality, which is the singular cause of every change in a continually changing world. It is why he frequently mentions individual freedom given to humankind in Islam. According to him, like all individuals, the architect will use this freedom, and will make decisions on "shape." Cansever's commitment to individual freedom and the architect's responsibility towards "space and time" brings his attitude closer to the modernist attitude. However, the architect's responsibility for the "space-time" or the historical and social conditions is quite different from what modernist ideologues think. At a meeting, the difference was summarized in his proposal on the fact that architects should not have placed the dome on the floor. The "modernist" mosques, which were the source of criticism, had brought the dilemma of protecting the visual memories of the Ottoman dome, on the one hand, and denying all historical references to it, on the other side. Cansever criticized both the use of historical references under the modernist identity and the attitude towards denying the "family" to which these references belong in terms of the nature of the modernist tendency. The "spacetime" (historical-social conditions) dimension built on the phenomenon of change, one of the main dynamics of his thought, prevent Cansever from being PostModernist. Also, his opposition to the arbitrary utilization of historical references without regarding semantic and syntactic relations made it impossible for him to become a modernist. Cansever's view is out of line; he is not a regular observer of Western discourse, so Cansever's idea is architecturally the only true opposition discourse of today's Turkey [2].

Understanding of Cansever's opposition discourse on Islam, Ottoman, and modern architecture will be possible by examining his structures.

\section{AN EVALUATION ON TURGUT CANSEVER'S STRUCTURES}

The restoration of Sadullah Pasha Mansion in 1949 was the first important experience of his professional life. In 1951, he founded his first architectural office with his partner Abdurrahman Hancl. There are 86 projects in which Cansever is a project owner. Some of these are only sketched works like grave designs. Protection, dissemination, and coastal planning projects that he did when employed in some public institutions are important in terms of showing his approach to some problematic areas of the modern city than their formal preferences and are mostly at the proposed level [11].

Cansever has structures in and out of Turkey. Some of these include the proposals produced through competition projects. According to Tanyeli [2], Cansever must have understood that the "native" architecture could not be created by imported discourse. After seeing the sovereignty period of the nationalist discourses in the 1940 s, the Internationalist discourses in the 1950 s and the local imported discourses in the 1960s. His own words, "the low-level, withered form effects of Central European village architecture," which characterizes the 1940s of Turkey, explains the reaction to the German architectural discourse brought to the country by Bonatz and counterparts. With this response, he realized the Buyukada Anatolian Club Hotel (1950-57, A.Hancı). This structure is the first real modern product made in Turkey after the 1930s. Starting from that period, Cansever had been steadily advancing towards creating a more indigenous architecture and discourse. Cansever, who began to work in the area of urban reconstruction and conservation with Beyazit square design in 1958, took part in many short- term tasks in these areas. The Turkish Historical Institute building, Karatepe Aslantaș Open Air Museum (1954), Ertegün house in Bodrum (1971- 73), Şişli Terakki High School Campus (1974), Bodrum-Demir holiday houses are important stages of this development. In the course of his professional life, he gradually moved away from the modernist line and discourse, finally, as in the 1980s, reached an Islamic-traditionalist discourse as in Bodrum underwater Archeology Institute building (1983) and Karakaş Mosque (1991) projects [2].

Anadolu Club Hotel Building, Buyukada, Istanbul, Turkey, 1951-1957, (with Abdurrahman HancI):

It is a project that Cansever won the first prize as a result of a competition, with Abdurrahman Hancl. This hotel building stands out with the concern of evaluating the historical features of local architecture, designed in an environment where international style is effective, against the influences of styles coming 
from the west. In parallel with this idea, a simple concept, which is consistent with the repetition of the tension of standard elements, and which the mesh surfaces on the rear side are stretched, attracts attention [4]. The road facade was created with repeated open and closed sunshades. On the other hand, gross concrete was used. Balconies in front of the rooms also functioned as sun protection [12]. According to Cansever, the front of the building is facing the future and modernism, and the back is facing the Ottoman Empire. Side facade corner solutions and exits were made, taking into account the properties in the Turkish housings. Instead of imitation, it is aimed to create an architectural language to match the old and the new [11]. It is one of the few buildings of Cansever, built under the influence of Western architects. From a planimetric point of view, a morphological similarity is mainly observed with the Swiss Pavilion of Le Corbusier, on the Paris University site. It is one of the important examples of modern architecture in Turkey. Although its construction took so long, it was described as the first building in Turkey, giving the good news that 1940 s traditionalism was surpassed (Figure 1) [1].
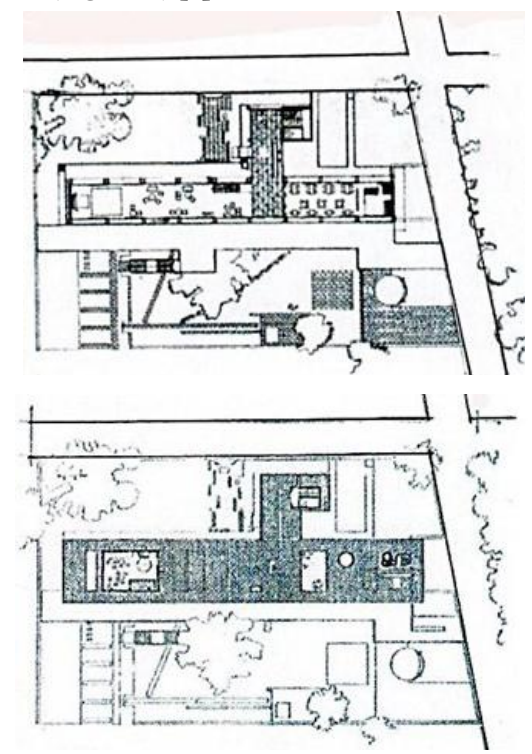

Plan

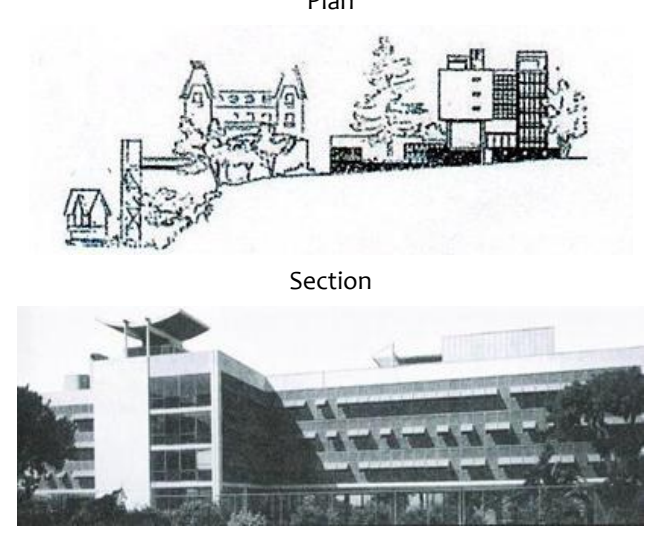

Appearance
Turkish Historical Society Building, Ankara, Turkey, 1951-1967 (with Ertur Yener):

This building, awarded the Aga Khan Architecture Award in 1980, is a successful example of architecture combining contemporary building technology with traditional ideas. The jury noted that the building reacts "against the International Style that has characterized building in Ankara since the $1930 \mathrm{~s}$ and is an example of what can be learned from tradition and a pointer to a more appropriate architectural language" [13]. In this design, which includes conference hall, bookstores on the ground floor, and library hall, reading hall, some libraries, and office rooms on the upper floor, the concept of gathering around a central courtyard reflects the inward-oriented character of Ottoman structures [4]. In many writings, Cansever states that the structure was designed around a courtyard, continuing the characteristics of the plans of Ottoman Mosque venues or madrasahs with the middle courtyard. According to the architect, these typologies reflect the principle of integrity, which enables the continuation of the understanding of "the equality of every individual in front of God in Islamic belief" [3]. The Turkish Historical Society building, which manifests itself as a reaction to the international style made in Ankara since the 1930s, has a concept in which modern materials are used in a conscious approach with a traditional understanding. The reinforced concrete skeleton, the Ankara stone, polished Marmara marble, the aluminum frames, and wooden cages are contrasted with each other. The dark red stone walls, the outer solid mass, the tectonic character, and the architectural identity reminding the formal organization of the Ottoman madrasah makes itself the focal point in its environment [4]. Cansever aims to create a structure peculiar to Turkey in line with religious and traditional ideals and to adapt them to his culture and geography, by not giving up the universal principles he considers as positive. In this way, to reach a contemporary style and at the same time to ensure cultural continuity (figure 2) [3].
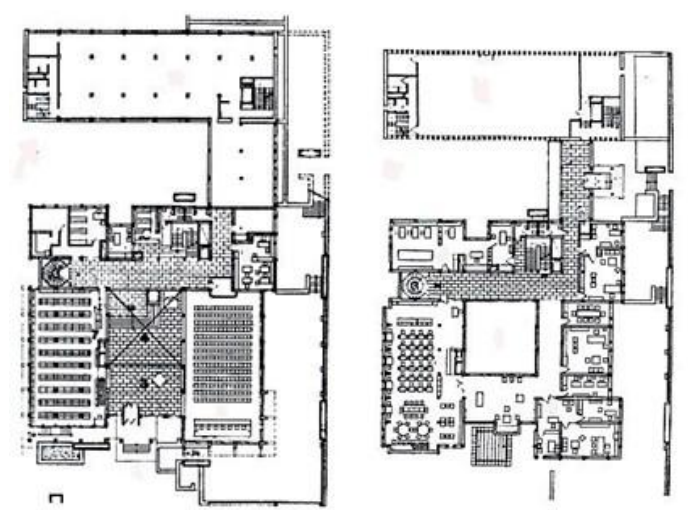

Plan

Figure 1. Anatolia Club Hotel Building, Buyukada, Istanbul, Turkey, 1951-1957 [11] 

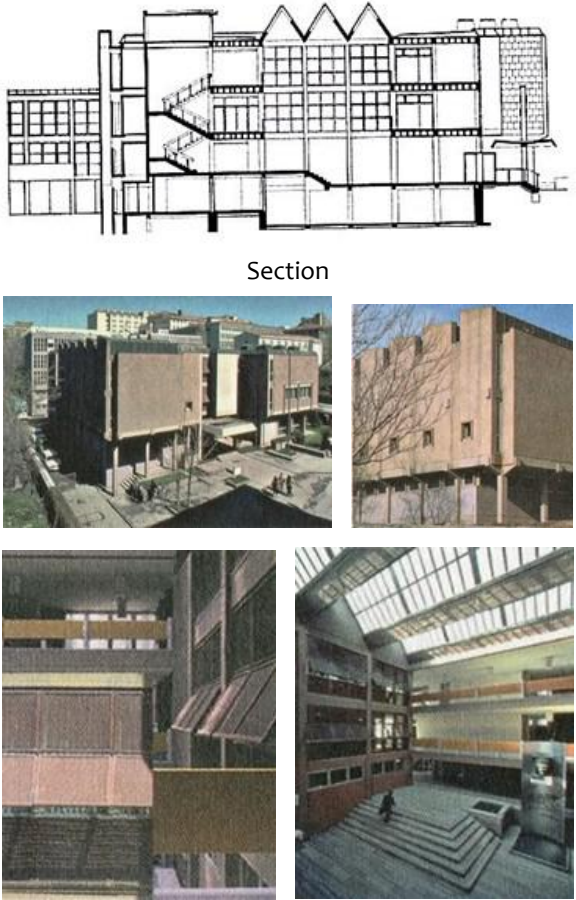

Appearance

Figure 2. Turkish Historical Society Building, Ankara, Türkiye, 1951 $-1967,1973$ [11]

Karatepe Aslantaş Open Air Museum, Adana, Turkey, 1954-1961

The preliminary project of "Karatepe Canopies" was made by the Italian architect Franco Minissi. Franco Minissi (1919-1996) is an architect known for his in-situ conservation works on archaeological sites, especially for his museum designs. Beatrice A. Vivio, in his monograph of Franco Minissi, states that Minissi drew the Karatepe project between 1952-1954 and that the project was presented to the Turkish authorities in 1955 and built with some revisions. The building process was carried out by Turgut Cansever. Karatepe Canopies are an inspiring source for Cansever's later productions. The new architectural language offered by the canopies is always seen in Cansever's structures [15].

It consists of eaves protecting the northern and southern doors of the settlement belonging to the late Hittite period in Karatepe National Park. The eaves, designed to follow the plan directions of the doors which are understood to be organized by taking into account human orientations, have a character that reflects the mutual tension of the techniques applied in nature by spreading to the land as well as being in harmony with the old works. The design of the guest house, consisting of services such as a library, guest room, is close to the human scale, resistant to the forces of nature, and attracts attention with its simplicity [4].

Although the eaves can be designed in accordance with the historical remains, the fact that it reflects not a clear geometry but the uneven geometry of the underlying structures is an expression of an original posture. The eaves, which are shaped to preserve existing values, disclaim a steep angle of view. The individual preference of the architect here refers to that he accepts that what exists and what is important is the historical remains below and that his work fits him. In addition to this sensitivity, its relationship with nature carries the cover-eaves to another metaphorical level (figure 3). The use of the material in natural texture and color, the design decisions such as putting the purpose of the work in the best-reflected form, represents a Brutalist comprehension. The selection of materials demonstrates a new understanding that the new structure is intended to maintain its existence within nature for a long time and respects local characteristics. Light is also an essential issue in design and spatial impact. The eaves are arranged to form a balanced light-shadow relationship to protect the covered artifacts and not leave them in the dark.

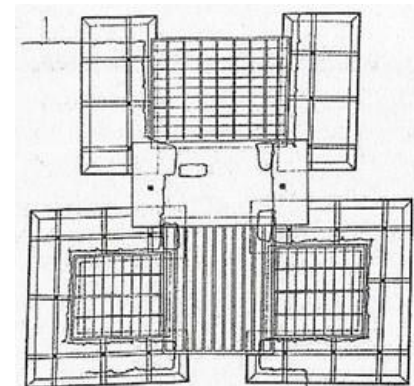

Plan
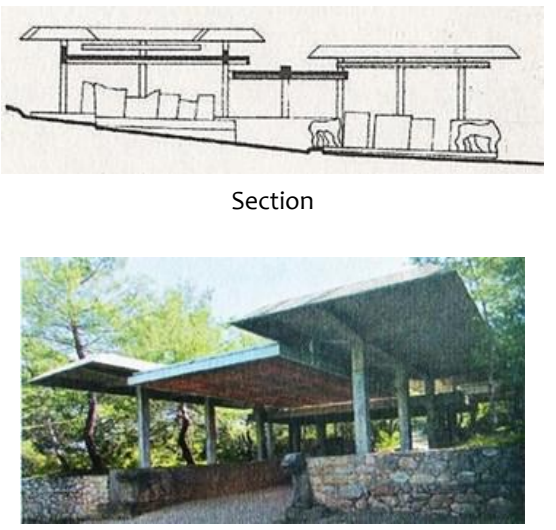

Appearance

Figure 3: Karatepe Aslantas Open Air Museum, Adana, Turkey, 1954-1961, 1973 [11]

\section{Ertegun House Restoration, Bodrum, Mugla, Turkey,} 1971-1973:

Ertegun house is located between a garden on one side and the sea and castle on the other side. Cansever defined the house as a part of the environment and shaped its architecture as being integrated with its surroundings, allowing its user to watch the garden on one side and the sea, landscape on the other side (Figure 4).

Ertegun house is an example of the restitution of an Ottoman period structure. The structure reveals 
the conscious evaluation of the relationship between the old and the new. By ensuring the continuity of the Ottoman's life and iwan (vaulted or domed space recessed from a central hall or court) form, he created a new formation that shows the traces of the past [15]. In Cansever's residential projects, the ground floors are considered together with the garden to the extent that the topography allows, attracting attention with their qualities such as the opening to nature and getting into nature in terms of visual and functional. The intermediate floors are essential for clarifying the plan diagram and they are visually connected to the outside space. The connection of the interior space to the outside is not directly in the form of opening to the public area. This relationship is indirectly established with the garden, which is an intermediate space [11]. In this structure, the opening and closing of the window lids connecting outdoors, and the asymmetrical arrangement of the windows provide a sensible movement, allowing the structure to become a living entity.

When designing the Ertegun house, Cansever shaped the geometry of the building with a dynamism asymmetrically and opened to transformations, taking into account the "state of being in existence." The opening and closing of the window doors connecting the interior, and the asymmetrical arrangement of the windows provided an unusual movement, and so the structure became a living entity. It refers to an architectural order that responds to the different needs of people living in the building, and that can be transformed with them. Cansever emphasizes the intangible structure of the human being while building this architecture making an individual feel the spirituality. The interior of the building, which is described by Cansever as "added to the world with purification," is transformed into a material-free environment through deaf stone walls, a plain reinforced concrete ceiling, and flat sharp internal lines [11]. The building won Aga Khan Awards for Architecture in 1980. The jury gave a citation to this project for "the imaginative combination and re-use of two 100-year-old seaside houses and for demonstrating that old structures can be transformed into functional as well as beautiful environments without resorting to direct imitation. The different language of the linear addition, which joins the two houses at the back, stands in harmony with the existing architecture and shows how successfully the new can be integrated with the old. This project is also significant for having encouraged the trend toward conservation in the Bodrum area, where an important traditional house type is fast disappearing [16].
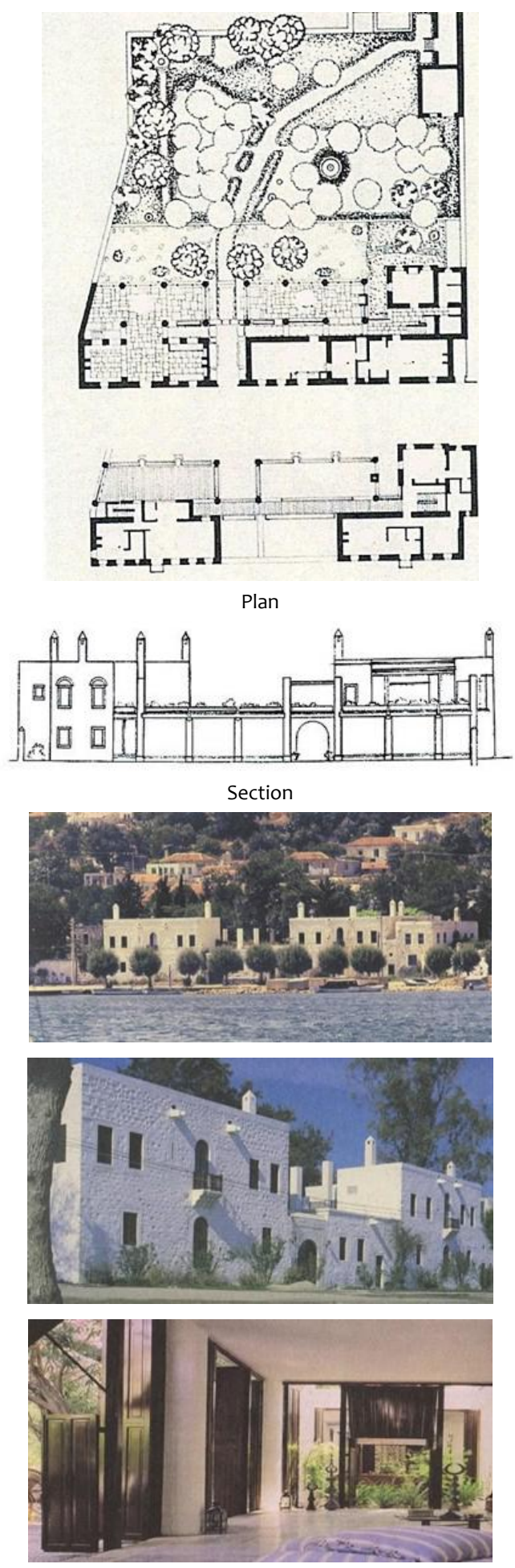

Appearance

Figure 4. Ertegun House Restoration, Bodrum, Mugla, Turkey, 1971-1973 [11]

Şişli Terakki High School Campus-Foundation Kindergarten, Istanbul, Turkey, 1974-78

This school complex consists of kindergarten, primary school, dormitories, sports hall, etc. The formation of a close relationship between cultural activities such as education and exhibition, 
conferences, and sports is the basis of the functional organization. Theory, practice, the establishment of relations of educational activities and the flexibility for the future constitute the foundations of the design idea [15]. Şişli Terakki High School Foundation Kindergarten was designed as one of the precursors of kindergarten structure in Turkey, without converting from another structure. Şişli Terakki Foundation educational campus was designed to define the requirements of all student groups from kindergarten to high school. Spatial fiction was created in the context of relations between education and cultural activities. For this purpose, exhibitions, conferences and sporting events constitute the essential elements of the organizational scheme. However, only kindergarten and primary school buildings were built (figure 5).

According to Öztepe, the structure is one of the embodiments of Turgut Cansever's "ideal world," which he wrote in many texts. The building which took a space in Istanbul topography for about 15 years is the practice of architectural problems' solution that Cansever developed as "standards," "upper coverbody wall transitions," "relationship with the ground" and "context." Cansever expressed the architectural problem through different planes and subjects in his book "not to put the dome on the ground" (1997). The idea of "not putting the dome on the ground" refers to the classical Ottoman Mosque architecture. It defines the relationship between the whole and the place in which each architectural element should be constructed in its context. The main editor of the building is the vault. Cansever interpreted the vault as a manifestation in the interior of the sky [7], [9].

The symmetry of the structure is designed as two class. The upper cover in the vault form is characteristic of the structure. There is a small break in the structure with a linear planimeter extending to the ground floor. Class facades are opened to the garden through sliding aluminum joinery from wall to wall. The classes forming the basic unit in kindergarten and primary school buildings were articulated to define a whole on condition plan scale, independent of the main mass in unique space property. Building elements such as vault, eaves, gargoyle, wooden lattice were repeated in these structures as in previous designs [7].

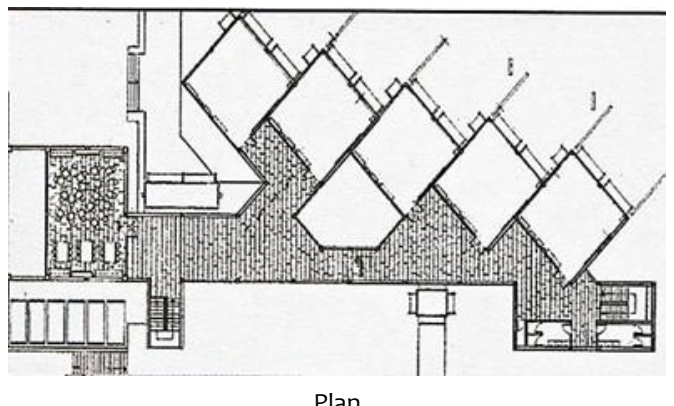

Plan

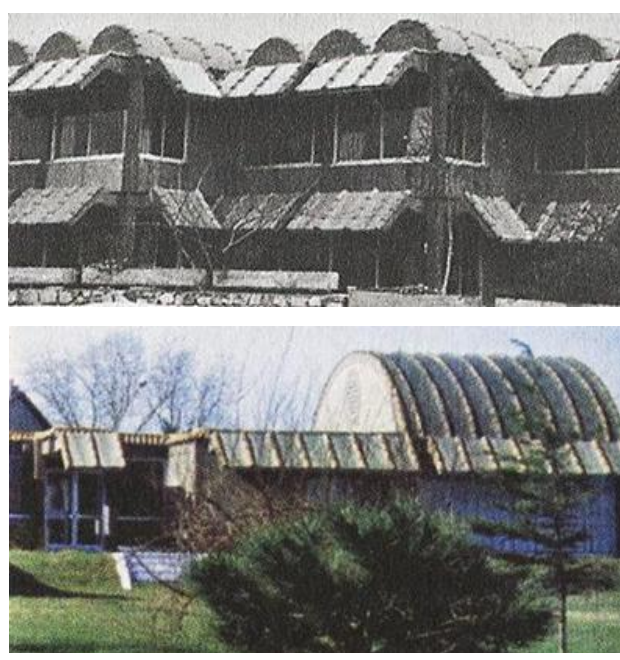

Appearance

Figure 5: Şişli Terakki High School Campus and Foundation kindergarten, Istanbul, Turkey, 1974-78 [11]

Demir Holiday Houses, Bodrum, Mugla, Turkey, 1983 (together with Emine-Mehmet Ögün and Feyza Cansever)

Demir holiday houses, which won the Aga Khan Award for Architecture in 1992, is a design consisting of three hotels and 500 houses in a valley surrounded by forests. Since its inception, the village has been shaped by environmental concerns - namely conservation of trees and soil, exclusion of cars wherever possible, protection of the shoreline from erosion, and the sea from pollution. The jury found the village refined yet simple. The well crafted, beautifully sited houses set a high standard for architectural design, craftsmanship and commercial land development [17]. The hotel structures, which were usually 3-4 storeys, designed in three different positions in the middle of the coast, sea, and valley, to direct the settlement of 1-2 storey residences [4]. Although the civilian architectural elements had been reused in the Demir houses, the structure of Ottoman housing settlements and the elements that bind the region's cultural background are used in integrity by Cansever. The precast window frames, chimneys or consoles differentiated the architectural expression from traditional ones [18].

In this project, which is thought to be an architectural concept suitable for the housing tradition of Bodrum, the composition suggested by Cansever through Ertegun House and other works emphasize values and behaviors such as the respect for the rules of nature, simplicity, clarity, neighborly relations [4]. In the design, each structure was sought to be a part of the local realities, and a series of architectural standards were tried to be established for the architectural integrity and stylistic consistency of the settlement. Houses consist of different types of plans. Among the houses, private living areas were arranged for guests or for various age groups with the addition of one-room elements, similar to the traditional Turkish House's "selamlik" (the portion of a house reserved for men) and annex room [12]. 
Demir houses are not built as a consumption object, unlike many holiday settlements on the southern coast, but are built as a settlement that offers the real values of architecture. The Islamic thought of the architect, the structure of Ottoman housing settlements, and the elements that connect the cultural history of the region were used in integrity. Demir houses show that even the limited principles for architecture allow for so many options and that Cansever's promises enable the creation of spaces. This diversity, which does not allow for the same, makes it possible for Architecture to turn into a living place rather than a spectacle. The settlement created by the repetition of the home type does not create a routine order based on the repetition, nor does it create a mirroring effect. The streets between houses offer different, varied perspectives for their development in a pattern that is not based on linear and routine repetition. These paths provide different experiences with variable views as well as being references to past and local (figure 6) [19].

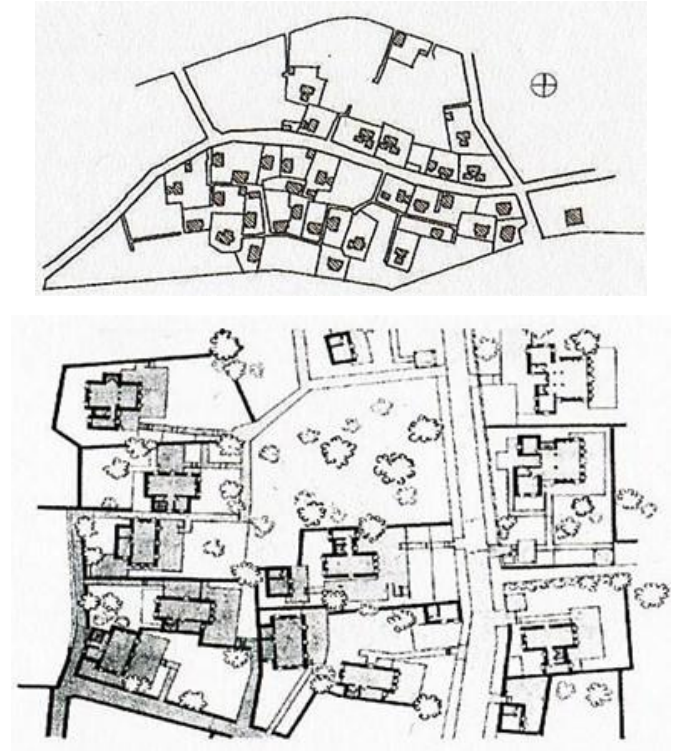

Plan
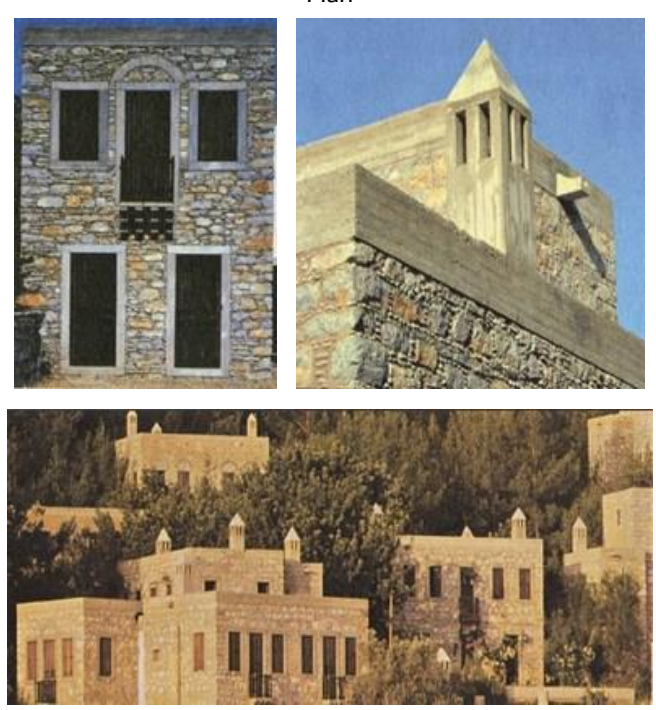
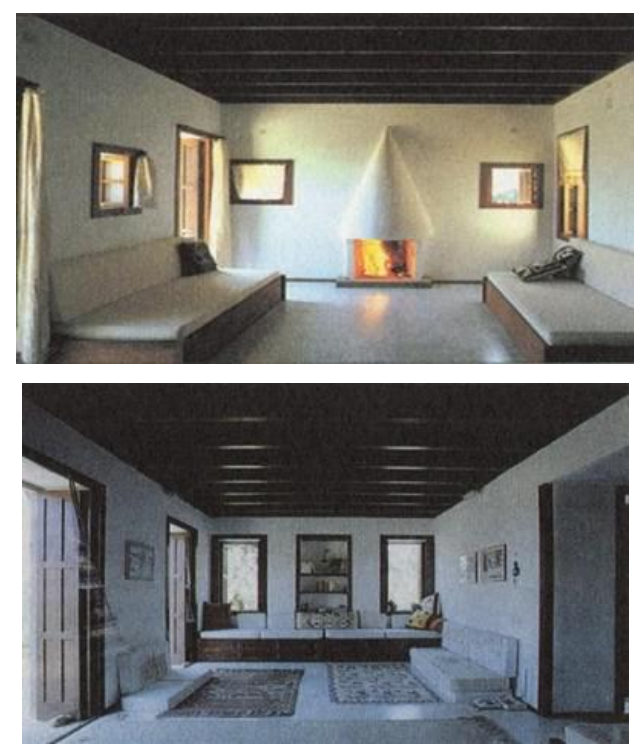

Appearance

Figure 6. Demir Holiday Houses, Bodrum, Muğla, Turkey, 1983 [11]

Underwater Archaeology Institute (INA), Bodrum, Mugla, Turkey, 1983 (with Feyza Cansever):

The center of the Underwater Archaeology Institute (INA) in Bodrum carrying out underwater archaeological studies in various countries. The workplaces are placed in a north-south direction as a precaution against heat, and the main entrance and the administration, library, offices, workshops, and meeting rooms of work sections are arranged around an open courtyard to the north by taking into consideration the plan of the Madrasah with courtyard. In order to provide the feeling of infinite space, local sensitivity was tried to be reflected in stone wall texture, wall joints, and wall coverings, in the institute where the openings are formed in all volumes towards the sky and in different directions; the expression with industrial tension was also made evident in precast concrete roof elements and jambs (figure 7) [4].

The building group can be considered as a social complex with the buildings offering different functions and the semi-open courtyards that harmonize with topography. Each unit that makes up the structure responds to a separate function. The accommodation unit was constructed independently of the whole building group, and the Institute building and the meeting and library buildings were connected with the vault-covered entrance area. The building group with this granular structure is reminiscent of the social complex forms. The references to civil architecture are observed in Demir houses, while the traces of monumental architectural elements are observed in this building. Settlement space organization and architectural elements take references from the Ottoman and Seljuk monumental architecture. Each of the rooms in the Institute building and the corridor opening to the courtyard is covered with vaults. By covering every place with a vault of its own, these places differentiate their 
existence on the whole.

On the one hand, they remind us of madrasah cells, each covered with a separate dome or vault. Again, this repeated movement gives information about the interiors on the front and adds to the expression of the adornment by means of repetition. Cansever states that all volumes are intended to provide an infinite sense of space with openings against the sky in different directions [19].

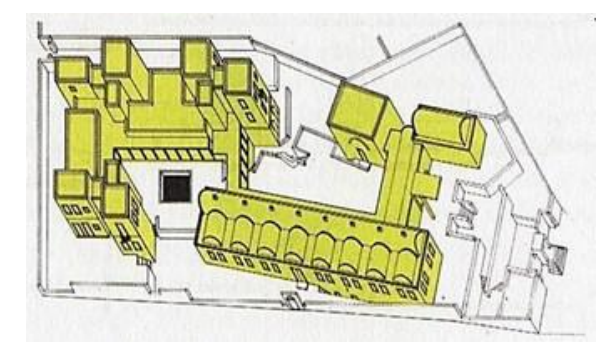

Plan
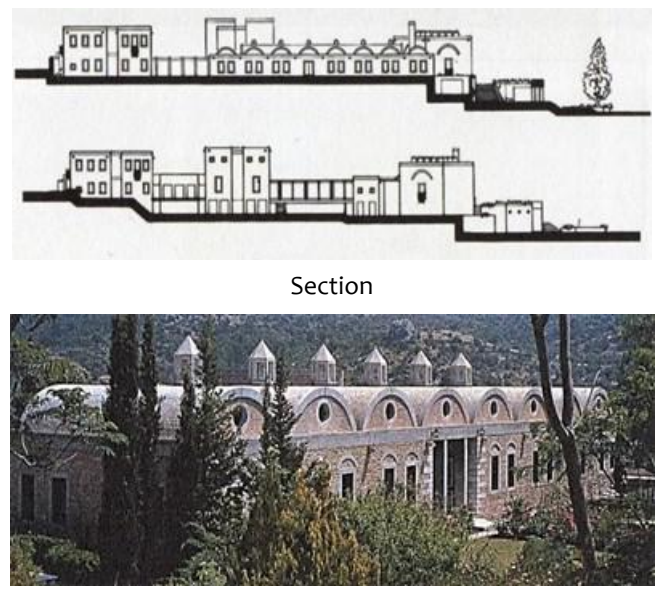

Appearance

Figure 7. Institute of Underwater Archeology (INA), Bodrum, Mugla, Turkey, 1983 [11]

Karakas Mosque Project: Antalya, Turkey, 1991:

Turgut Cansever was invited to prepare the necessary projects for environmental regulation of one of the important archaeological values of the province of Antalya. It is the Hadrian gate (three gates), which was built due to the visit of the Roman Emperor Hadrian to Antalya, and for the reconstruction of the Karakaş Mosque just across the three gates. The project was constructed to provide an appropriate unity in architectural and urban design dimensions between the buildings of the near period with the values that symbolize the various historical periods and to enable the destroyed Karakas Mosque to reach to a high value (figure 8) [4]. According to Tanyeli, the mosque of Cansever is a real and uncompromising historical experiment. The stacking construction carrier infrastructure was constructed using stones, bricks, and domes that were built with bricks, without a mould, just like the traditional Ottoman mosques. Its planimetry is also historical. The only element not seen in historical Mosque architecture is the ventilation-light lanterns located at the peak points of the domes. It has a function of providing air circulation through the dome which is vital in the Antalya climate. It is a successful design that shows that a different historicist attitude is possible in a society in which only the conformist form of historicism is dominant [2].
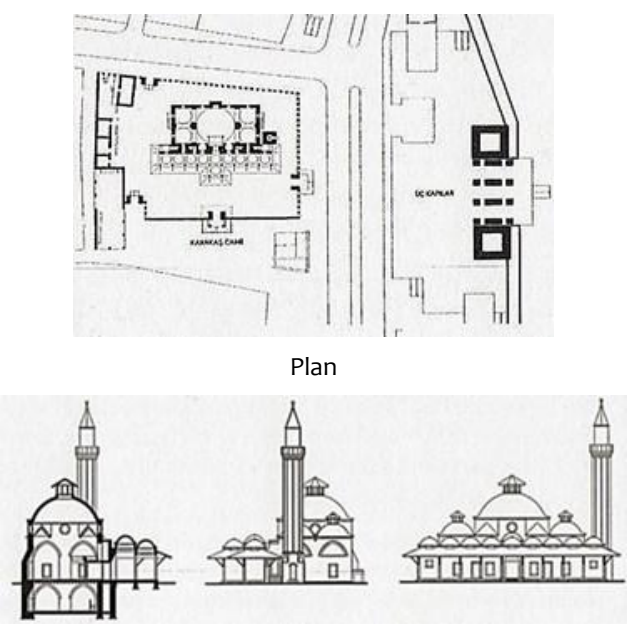

Section

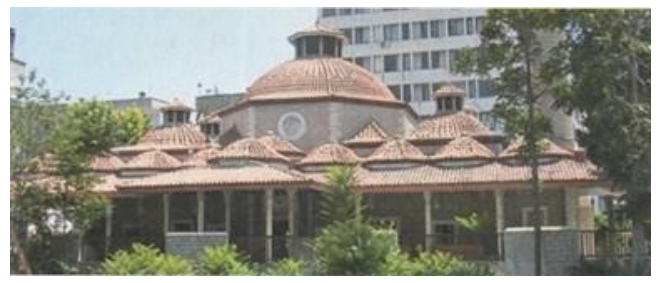

Appearance

Figure 8. Karakaș Mosque, Antalya, Turkey, 1991 [11]

\section{EVALUATION}

As stated by Tanyeli, Turgut Cansever's early buildings were the years when modern architectural contents were interpreted and tested. This period is followed by Ottoman civil architecture, Seljuk and monumental Ottoman architecture, Islamic religious and cultural influences.

After the 1980s, it can be concluded that the main characteristics of the monumental structures and the influences of the Islamic religion and culture have reached synthesis and are repeated with similar contents in almost all his buildings. In this section, eight structures regarding three periods; the design concept that constitutes the background of Cansever's design idea will be analyzed in accordance with the parameters of form, structure and material usage. The tables will be supported by the visuals of many building types, which are mentioned in the literature as the source of Cansever's designs. Undoubtedly, these visuals are not one-to-one structures in which the designer is influenced. They are examples that will help to understand the subject (figure 9, figure 10, figure 11, figure 12). 


The first years and experiences in the profession:
The years in which modern architectural contents
were interpreted and tested. The repetition of
pure forms is observed with contemporary
materials such as brutal concrete and aluminum.
Although they were early period buildings, it is
seen that important elements of Ottoman civil
architecture are integrated with modern language.
(Lattices, wide canopies, span amount and ratio
etc.). Although the Seljuk and Ottoman grand
architectural plan schemes are modernized and
used, buildings have more modern elements in
terms of architectural language.

\begin{tabular}{l|l}
$\begin{array}{l}\text { Anadolu } \\
\text { Club } \\
\text { Hotel } \\
\text { building, } \\
\text { 1951-1957 }\end{array}$ & $\begin{array}{l}\text { Architectural concept: The traces of } \\
\text { the ruins on the ground are essential } \\
\text { data on the formation of the } \\
\text { canopies. The wide canopies are one } \\
\text { of the important features of Ottoman } \\
\text { civil architecture. } \\
\text { Form/structure and material: The } \\
\text { wide and large canopies in this design } \\
\text { are also constructed from brutal } \\
\text { concrete. The guest house has cubic } \\
\text { forms. The materials used were } \\
\text { chosen to accommodate the effects } \\
\text { of time (such as brutal concrete, and } \\
\text { oxidized steel, etc.). The building has } \\
\text { modern lines in general. }\end{array}$ \\
\end{tabular}
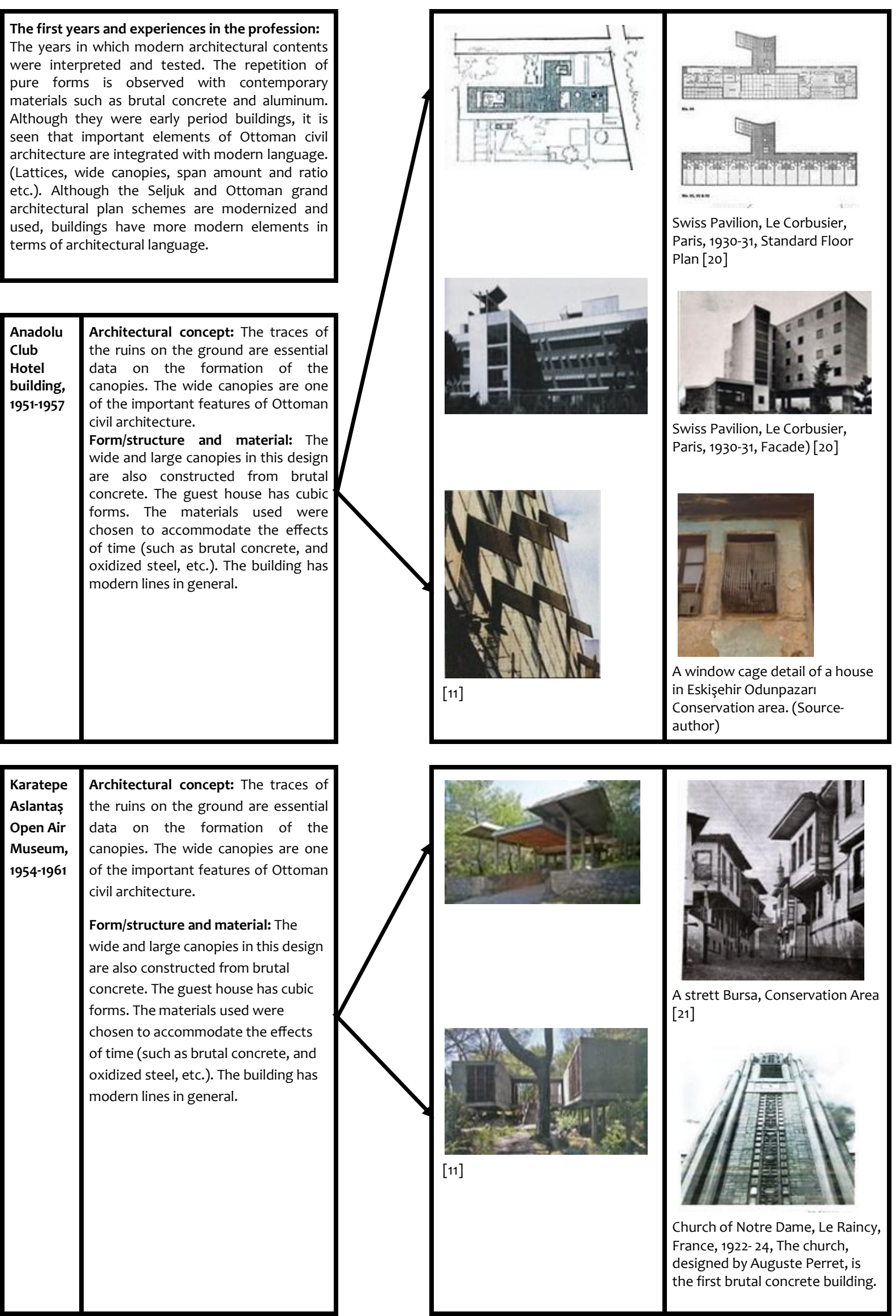

Figure 9. The first year of the profession 


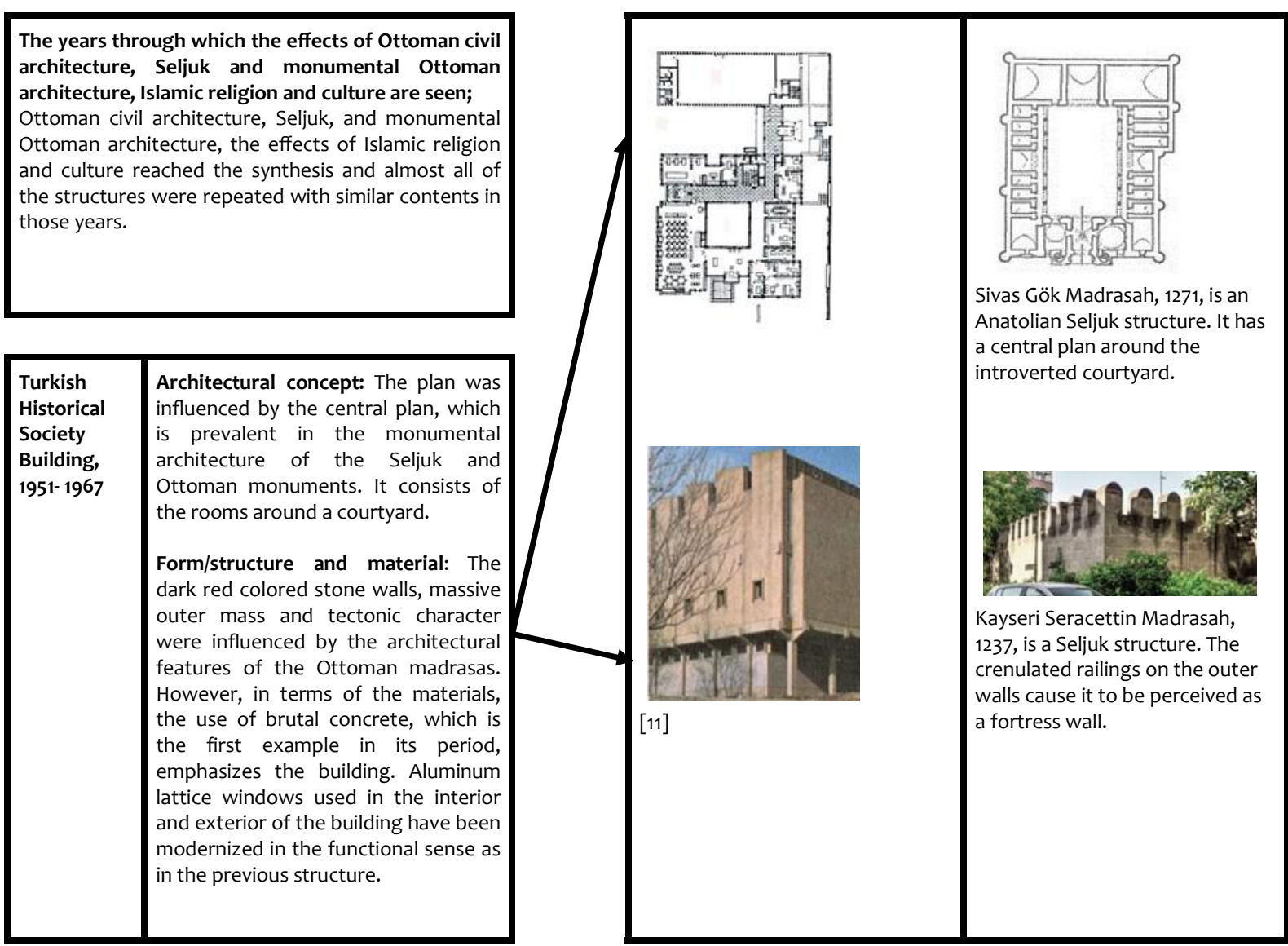

\begin{tabular}{|l|l|}
\hline $\begin{array}{l}\text { Ertegun } \\
\text { House } \\
\text { Restoration, } \\
\mathbf{1 9 7 1 - 1 9 7 3}\end{array}$ \\
$\begin{array}{l}\text { Architectural concept: The building } \\
\text { reflecting the features of Bodrum's } \\
\text { traditional housing architecture } \\
\text { (Ottoman civil architecture) is a } \\
\text { restoration project. Modern additions } \\
\text { that contemporary houses necessitate } \\
\text { are implemented to the building, } \\
\text { constructed with the idea of "being } \\
\text { articulated to the world of the } \\
\text { purified environment from the } \\
\text { matters." }\end{array}$ \\
$\begin{array}{l}\text { Form/structure and material: In the } \\
\text { ground level of the house facing the } \\
\text { garden, the wide and big windows } \\
\text { opened when necessary supply } \\
\text { integrity with the garden. As it is seen } \\
\text { in traditional houses, the stone is used } \\
\text { in walls; concrete in-ground; wood in } \\
\text { ceilings. There are wooden shutters in } \\
\text { windows, opening to the exterior. }\end{array}$
\end{tabular}

Figure 10. The years through which the effects of Ottoman civil architecture, Seljuk and monumental Ottoman architecture, and also Islamic religion and culture. 

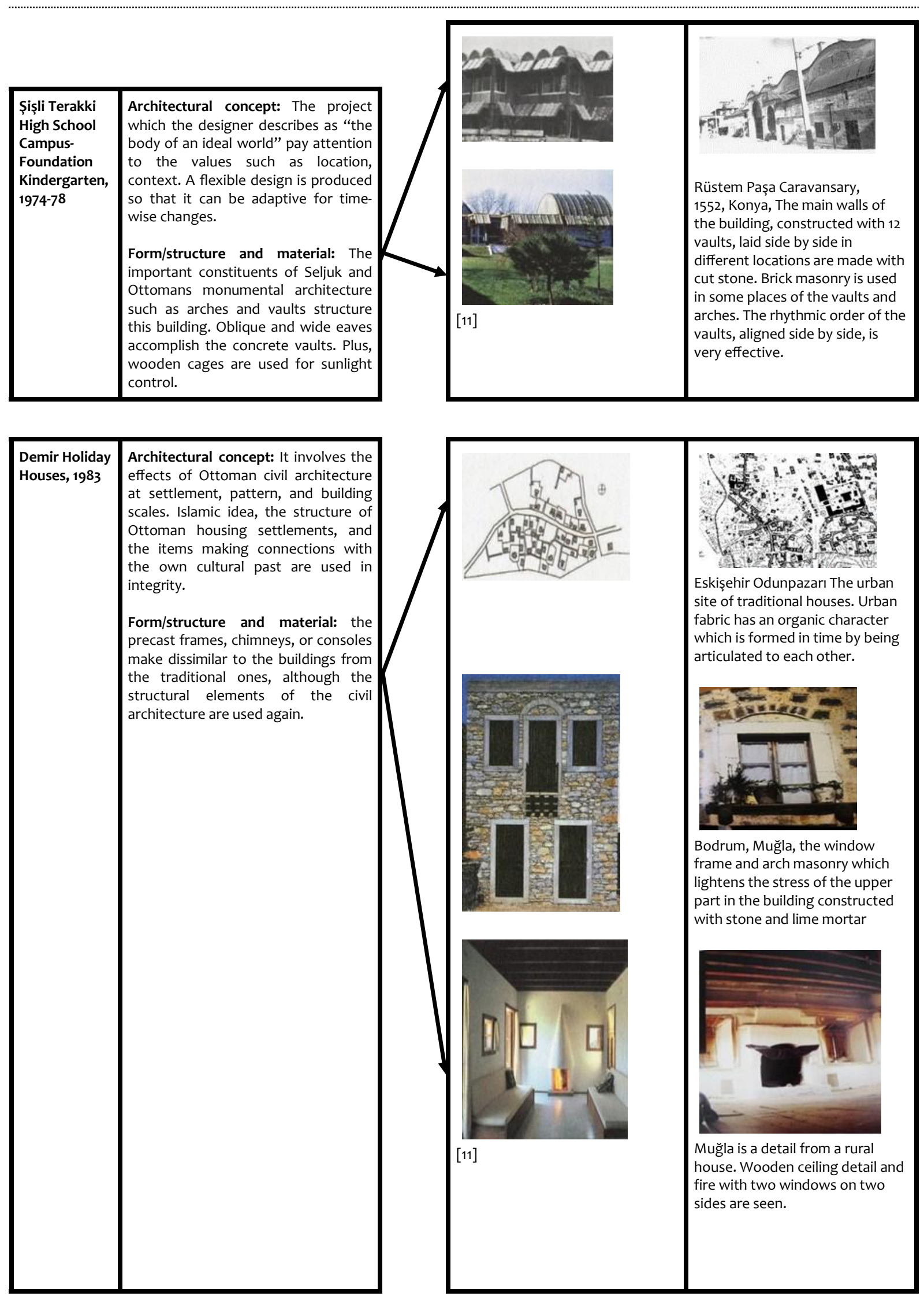

Figure 11. The years through which the effects of Ottoman civil architecture, Seljuk and monumental Ottoman architecture, and also Islamic religion and culture. 
The years through when the whole experiences have reached a synthesis:

It is the years when Islam religion and culture enter a combination and being repeated of them with similar contents for almost all of his buildings. It is pronounced that the buildings of this period are the product of an Islamist and traditionalist synthesis. It is a subject of re-design of climatic and topographic data with traditional material and contemporary techniques. The success of this synthesis can be clearer in detail. He does not repeat constructing manners. It is a period that the modern and individual interpretations are mighty. The main components of Seljuk and monumental Ottoman architecture and Islamic architecture, such as vault, dome and skylight, are repeated. The appearing of his discourses to buildings is strengthened with Islamic concepts and contents.

\begin{tabular}{l|l}
\hline $\begin{array}{l}\text { Underwater } \\
\text { Archaeolog } \\
\text { y Institute } \\
\text { (INA), 1983 }\end{array}$ & $\begin{array}{l}\text { Architectural concept: The } \\
\text { orientation to the sky with eternal } \\
\text { space sense is seen in the building. } \\
\text { This sense is strengthened with the } \\
\text { dome, vaults, and skylight apertures. } \\
\text { The repetition of social complex plans } \\
\text { is seen. }\end{array}$ \\
$\begin{array}{l}\text { Form/structure and material: The } \\
\text { reinforced concrete structure of the } \\
\text { building is shored up with stone walls. } \\
\text { The repeating vaults as Şişi Terakki } \\
\text { Building are closed to the exterior for } \\
\text { the hot climate. }\end{array}$ \\
\end{tabular}

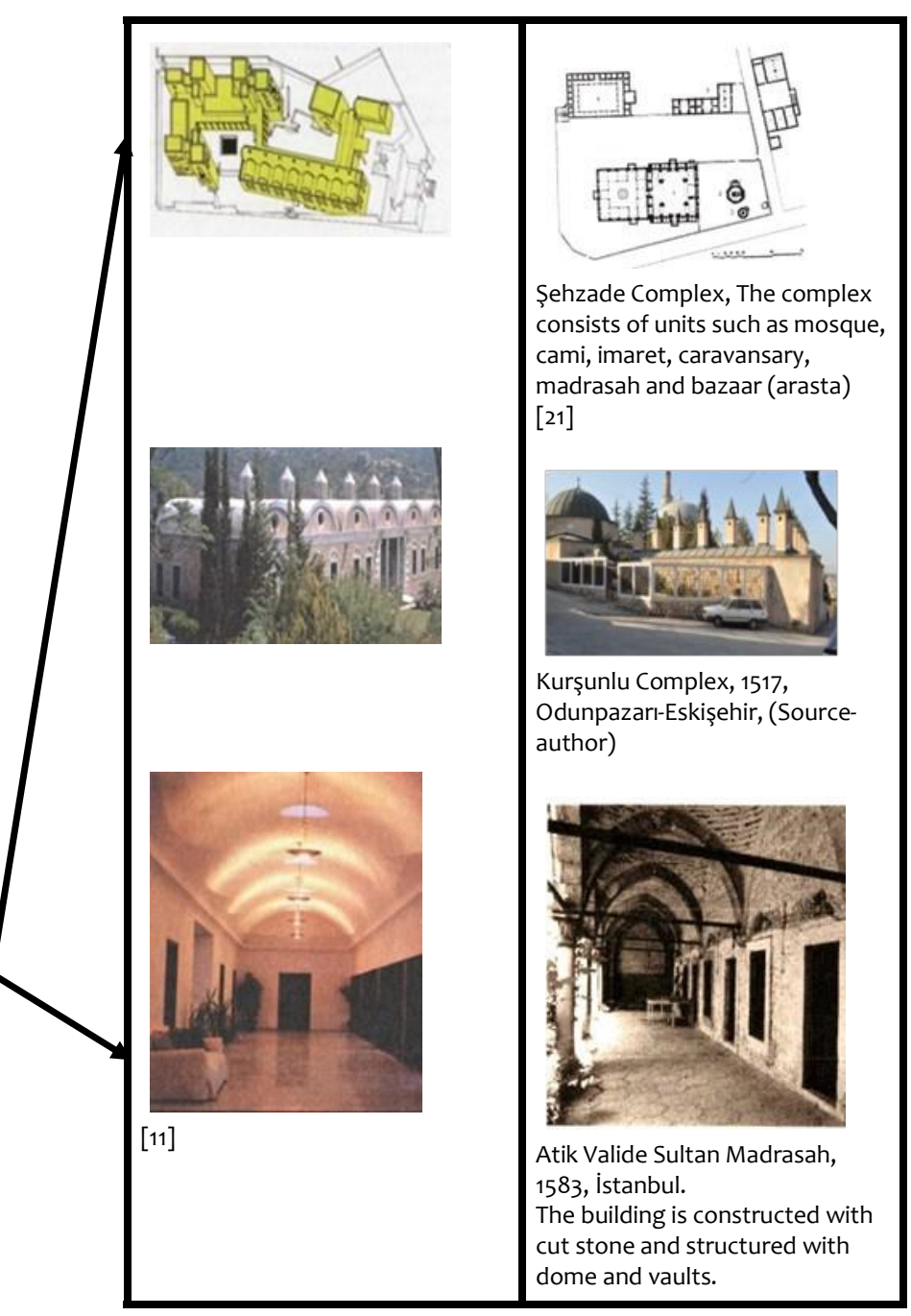

\begin{tabular}{|c|c|c|c|}
\hline $\begin{array}{l}\text { Karakas } \\
\text { Mosque } \\
\text { Project, } \\
1991\end{array}$ & $\begin{array}{l}\text { Architectural concept: It is the } \\
\text { repetition of Ottoman Mosque } \\
\text { typology. For this reason, it is found as } \\
\text { a historicist work of him. Many domes } \\
\text { form it in different sizes. } \\
\text { Form/structure and material: the } \\
\text { building is constructed with a solid- } \\
\text { masonry substructure with stone and } \\
\text { brick material and over it, a dome } \\
\text { structured with brick material without } \\
\text { mold just as the traditional Ottoman } \\
\text { mosques. Despite that daylight hole } \\
\text { over the dome is not used widely in } \\
\text { traditional mosque architecture, it is } \\
\text { preferred for the hot and humid } \\
\text { climatic conditions of Antalya. Similar } \\
\text { usage is seen in the Ottoman period } \\
\text { of imaret buildings. }\end{array}$ & $\begin{array}{l}\text { Karakaş Mosque, Antalya, } \\
\text { Türkiye, } 1991 \\
{[11]}\end{array}$ & $\begin{array}{l}\text { Haseki Hürrem Sultan Imaret, } \\
\text { 1540, İstanbul, (Imaret is the } \\
\text { name of the group of buildings } \\
\text { such as mosque, tomb, } \\
\text { madrasah.) } \\
\text { It is an early Ottoman Period } \\
\text { building. In the middle of the } \\
\text { dome, there is an upper window } \\
\text { for daylight }\end{array}$ \\
\hline
\end{tabular}

Figure 12. The years through when the whole experiences have reached a synthesis 


\section{CONCLUSION}

The philosophies of life and the ways of understanding the world are the determinants of the concept used by designers in their structures. Turgut Cansever's commitment to the belief system in his understanding of life, his concern for understanding and sustaining the past, as well as his concern for supporting life with current values while maintaining it, are some reflections of the strong character in his structures.

The first period structures take place in the history of architecture as a criticism of the architectural environment of the 1940s in Turkey. The concept used in these structures is close to the modern concept but also contains local and cultural values. The attitude of the 1950 s and 6os that even existed in the Ottoman residence tradition, aiming at maintaining the relationship between human and nature, was interpreted by considering the architectural elements existing in the Islamic and Ottoman architecture, such as the bay window, cage, vault, etc., restructured together with contemporary materials. In the structures produced after the 80 years, the effects of Islamic religion may be observed to be dominant with sharper lines. They are oriented to the sky with the concerns of providing the sense of "infinite space" at both the planimetric level and the third dimension. All of its structures can be said to be dominated by simple, lean and clear geometric layouts.

As a result of simplicity in geometric layouts, he reveals a consistent, stable, strong structure identity. What makes the concept of Sufism strong in interiors is its success in filtering natural light into space delicately. Turgut Cansever cannot be called as a vernacular, regional, or modernist due to the in-depth content of the looking at the architecture forming his style. The understanding of Turgut Cansever's discourses, each of which is a manifesto, will be crucial for young architects to understand the history of Turkish architecture.

\section{REFERENCES}

[1] F. Sönmez \& S. Arslan, "Seyahat Aracılığıyla Dünyayı Görme, Seziş Ve Yorumlama: Turgut Cansever Üzerine Bir Aktif Okuma/Düşünme", Ege Mimarlık Dergisi, no:92,pp.38-41, 2016

[2] U. Tanyeli, "Çağdaş Mimarlıkta İslami içerik Sorunu ve Cansever", Çağdaş Türkiye Mimarları Dizisi 1, İstanbul, Boyut Press, pp. 7-21, 2001

[3] B. Yıldırım, "Mimarlıkta Modernite ve Süreklilik", M.Sc. thesis, ìstanbul, 2007

[4] Ibit, Çağdaş Türkiye Mimarları Dizisi 1, Çağdaş Türkiye Mimarları Dizisi 1. İstanbul: Boyut Press, pp. 7-21, 2001
[5] T. Cansever, Sonsuz Mekanın Peşinde, Selçuklu ve Osmanlı Sanatının Sütun Başlıkları. İstanbul: Klasik Press, 2010

[6] E. B. Burkut, "Osmanlı/Türk Evi Mekan Kurgusunu Modern Konut Mimarisinde Okumak", M.Sc. thesis, İstanbul, 2014

[7] O.Öztepe, “ístanbul Topoğrafyasında Sessizce Yiten Bir Turgut Cansever Yapısı: Şişli Terakki Vakfı Anaokulu”, Yapı Dergisi, no:430, pp. 54- 58, 2007

[8] T. Cansever, "Şehir, Kent ve Kültürü", No:8, Cogito. İstanbul: Yapı Kredi Kültür Sanat Press, 1996

[9] T. Cansever, Kubbeyi Yere Koymamak, İstanbul: Timaș Press, 2002

[10] T. Cansever, İslamda Şehir ve Mimari, İstanbul: Timaş Press, 2013

[11] H.i. Düzenli, Idrak ve İnşa, Turgut Cansever Mimarlığının iki Düzlemi. İstanbul: Klasik Press, 2009

[12] D. Hasol, 20. Yüzyıl Türkiye Mimarlığı. İstanbul: Yem Press, 2017

[13] R. Holod and D. Rastorfer, Turkish Historical Society. In Architecture and Community. New York: Aperture, 1983.

[14] A. KÖKSAL and G. Kalan, "Karatepe Saçakları ve Müelliflik Sorunu," mimarizm, 2016. [Online]. Available: http://www.mimarizm.com/koseyazilari/karatepe-sacaklari-ve-muellifliksorunu 126312. [Accessed: 10-Sep-2018].

[15] L.Ö. Ersal, Mimari Mekanın Biçimlendirilmesi ve Anlam Boyutu: Ontolojik Yaklaşım, M.Sc. thesis, İstanbul, 2013

[16] "Recipient of the Aga Khan Award for Architecture in 1980," Archnet, 1980. [Online]. Available: https://archnet.org/sites/51. [Accessed: 10-Sep-2018].

[17] "Recipient of the Aga Khan Award for Architecture in 1992.," Archnet, 1992. [Online]. Available: https://archnet.org/sites/771.

[18] N.Yılmaz, Osmanlı/TürkEvi Mekan Kurgusunu Modern Konut Mimarisinde Okumak, M.Sc. thesis, ìstanbul, 2014

[19] U. Demirgüç, Mimarlıkta Eleştirel Bölgeselcilik ve Turgut Cansever, M.Sc. thesis, İstanbul,2006

[20] R. Naja, "AD Classics: Swiss Pavilion / Le Corbusier," Archdaily, 2013. [Online]. Available: https://www.archdaily.com/358312/ad-classicsswiss-pavilion-le-corbusier. [Accessed: 10-Sep2018].

[21] D. Kuban, "An Ottoman Building Complex of the Sixteenth Century: The Sokollu Mosque and Its Dependencies in Istanbul," JSTOR, vol. 7, pp. 1939, 1968. 